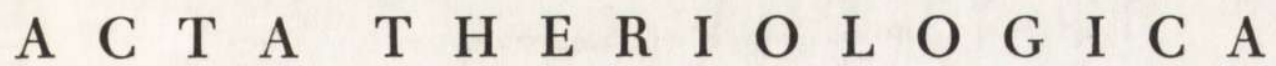 \\ VOL. $19,4: 55-67$ \\ BIAŁOWIEŻA \\ May, 1974
}

Piotr BIENKKOWKI \& Urszula MARSZAもEK

\section{Metabolism and Energy Budget in the Snow Vole}

[With 3 Tables \& 5 Figs.]

\begin{abstract}
The average daily metabolic rate $(A D M R)$, resting metabolic rate $(R M R)$, rhythm and sum of daily activity, as well as consumption and food utilization were investigated in the snow vole, Microtus nivalis $(\mathrm{N}=46)$, captured in Tatra Mountains $(1400$ to $1480 \mathrm{~m}$ above sea level). The $A D M R$ of $M$, nivalis at $15^{\circ} \mathrm{C}$ amounts to 3.82 , and at $20^{\circ} \mathrm{C}$ to 3.56 cc $\mathrm{O}_{\mathrm{o}} / \mathrm{g}$. hr. The relationship between $A D M R$ and body weight is described by the equations: for $15^{\circ} \mathrm{C}$ ADMR cc $\mathrm{O}_{2} / \mathrm{g} \mathrm{hr}=8.58 \mathrm{~W}^{-0.287}$, and at $20^{\circ} \mathrm{C}$ ADMR cc $\mathrm{O} / \mathrm{g} \mathrm{h}=8.75 \mathrm{~W}^{-0.264}$ The thermoneutral zone for snow vole is around $20^{\circ} \mathrm{C}$. At this temperature $R M R$ is equal to 6.33 $\mathrm{kcal} / \mathrm{kg}^{0.75} \mathrm{hr}$, and increases by $113.9 \%$ at $-10^{\circ} \mathrm{C}$. The efficiency of thermoregulation in this range amounts to $3.8 \% /{ }^{\circ} \mathrm{C}$. The temperature of vole's body depends to some extend on ambient temperature: in the range of 10 to $20^{\circ} \mathrm{C}$ it is constant and equal to $38.1^{\circ} \mathrm{C}$ but falls to 32.7 at $-5^{\circ} \mathrm{C}$. The sum of daily activity amounts to 8.9 hours. The rhythm of activity shows a biphasic $29.25 \mathrm{kcal}$ in the form of dried fruits of Vaccinium myrtillus; consumption of leaved stems is higher by $22.7 \%$. The daily energy budget $(D E B)$ calculated for summer and winter is almost identical and amounts to: $D E B$ (kcal/g day) $=1.25 W^{-0.264}$. During a day the vole weighing $33 \mathrm{~g}$ dissipates $16.4 \mathrm{kcal}$, or $0.497 \mathrm{kcal} / \mathrm{g}$, on the average.
\end{abstract}

\section{INTRODUCTION}

The snow vole, Microtus nivalis ( $\mathrm{M}$ a r t in s, 1842), is a rodent living in Poland exclusively in Tatra Mountains at a higher altitude than $1200 \mathrm{~m}$ above sea level (K ow a ls ki, 1957). It is most where it utilizes natural crevices and rocky corridors. In summer the snow vole migrates to the zone above dwarf mountain pine (up to $2250 \mathrm{~m}$ above sea level) where it can find sufficient food, but in winter it probably descends to lower regions (K ow a ls ki, 1957).

Since this animal lives, especially in winter, in extremely difficult conditions (low temperatures, long period of snow cover) one can expect several physiological adaptative traits to be present in this species. 
Hitherto Microtus nivalis was studied mainly in systematic respect (K ow a ls ki, 1967). Other investigations concerning biology and ecology of this species (M a r tirosjan, 1970), and morpho-physiological indices of its blood ( $\mathrm{K}$ os telecka-M y r ha, 1966), demonstrated some ecological and etological adaptations to the environment.

The present study was aimed at the estimation of certain physiological parameters and bionergetics of this species in order to construct the daily energy budget $(D E B)$.

\section{MATERIAL AND METHODS}

The snow voles used in the investigations were trapped in spring and autumn in the years $1970-72$ in the area of Morskie Oko and Rybi Potok in Tatras $\left(20^{\circ}\right.$ $\left.04^{\prime} \mathrm{E}, 49^{\circ} 09^{\prime} \mathrm{N}\right)$. They were captured at the altitude of 1400 to $1800 \mathrm{~m}$ above sea level in the zone of dwarf mountain pine (Pinus mughus) and in gullies on the western slopes of Morskie Oko valley in live-traps of the Białowieża type.

Before starting the experiments the animals were acclimatized to laboratory conditions for $2-3$ days at $12 \mathrm{hr}$ light rhythm. They were fed with oats and carrot given in excess and were supplied in water. Additionally they were fed with leaved stems or dried fruits of bilberries (Vaccinium myrtillus L.).

Metabolism, physical and chemical thermoregulation, rhythm of daily activity and sum of activity, as well as consumption and food utilization were investigated in the captured voles.

The average daily metabolic rate $(A D M R$ ) (Morrison \& Grodziński, 1968) was determined in 91 . metabolic chambers. The determinations were carried out in two series at 15 and $20^{\circ} \mathrm{C}$. During the experiment the voles were provided with a house and nest material, as well as feeding trough and water bottle. They were supplied with oats and water ad libitum. The experiments were carried out at 12 hour light rhythm. Altogether 42 animals were used in 31 experiments at $15^{\circ} \mathrm{C}$, and 21 experiments at $20^{\circ} \mathrm{C}$.

The curve of thermoregulation was determined by measuring resting metabolic rate $(R M R)$ in $460 \mathrm{ccm}$ chambers provided with wire net cages $5 \times 5 \times 10 \mathrm{~cm}$. The experiments were carried out in a modified Kalabukhov-Skvortzov respirometer (Górecki, 1968). The thermoregulation of snow voles was determined in the range of temperatures from $-15^{\circ} \mathrm{C}$ to $30^{\circ} \mathrm{C}$ at $5^{\circ}$ intervals. Altogether 46 animals were examined and 194 measurements were made.

At the same time rectal temperature of voles was determined in 30 animals staying in the ambient temperature from $-5^{\circ} \mathrm{C}$ to $20^{\circ} \mathrm{C}$.

The rhythm and sum of daily activity were determined in 11 animals. The experiments were carried out in large cages with nests. The nest houses were equipped with two-way switches enabling registration of time when the animal stays in the nest or outside it (Gór e c ki \& H a n u s z, 1968).

In a few voles energy expenses were estimated by means of metabolic cages (D r o ż ḋ, 1968), in which digestibility and assimilation of supplied food could be determined. Two types of diet were employed: in the first on the animals were supplied with dried fruits of bilberries (Vaccinium myrtillus L.), and in the second one - with leaved stems of this plant. In both cases the animals obtained additionally water and small amounts of standard diet which was consumed in negli- 
gible amounts. The energy values of food, feaces and urine were determined by combustion in a calorimetric bomb (G ó r e c k i, 1965).

The insulatory properties of vole's coat were also investigated. The determinations were made by means of Hill's katathermometer (Gębczyński \& O1s z e w ski, 1963).

Statistical analysis of the material included calculations of the mean, standard deviation, standard error and coefficient of variability in $\%$. The rectilinear regression was also employed for calculation of the correlation.

\section{RESULTS}

\section{Average Daily Metabolism}

The average daily metabolism rate $(A D M R)$ determined at $15^{\circ} \mathrm{C}$ in snow voles of mean body weight $33.3 \mathrm{~g}$ amounted to $3.82 \pm$ (S.D.) 0.68 . The same value determined at $20^{\circ} \mathrm{C}$ in $32.8 \mathrm{~g}$ voles amounted to $3.56 \pm$ \pm 0.60 . The obtained results were recalculated for calories assuming

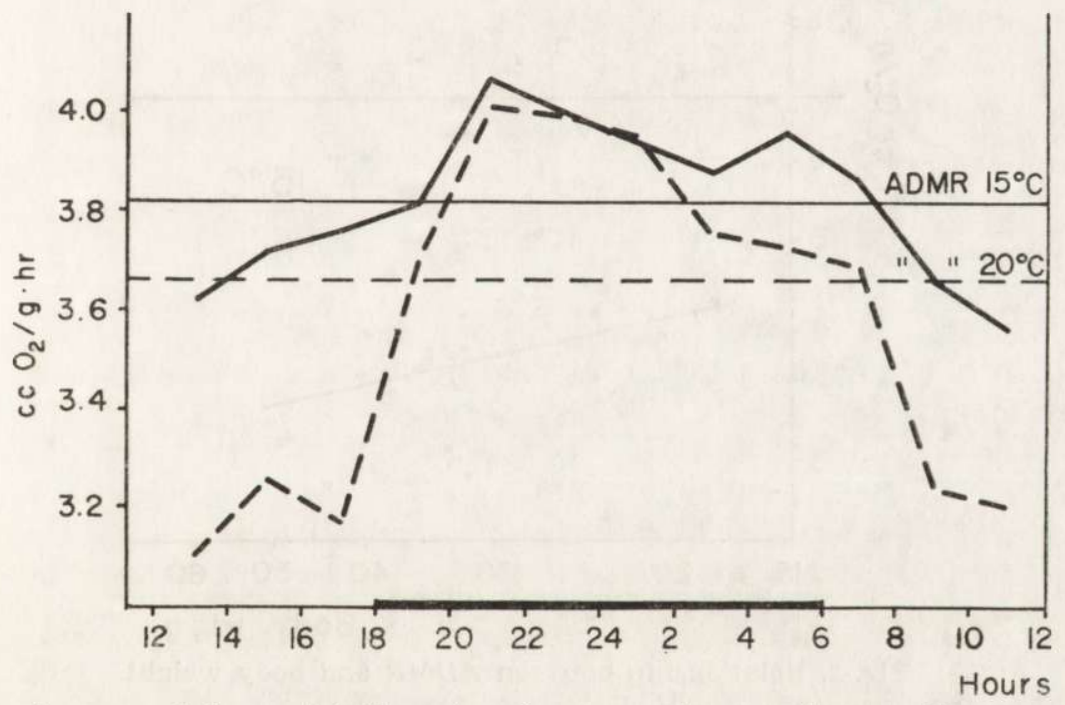

Fig. 1. Average daily metabolic rate of snow voles; continuous line - $A D M R$ at $15^{\circ} \mathrm{C}$, broken line $-A D M R$ at $20^{\circ} \mathrm{C}$.

$K Q=0.8$, i.e. caloric equivalent of $11 \mathrm{O}_{2}$ equal to $4.8 \mathrm{kcal}$. The corresponding figures are 0.440 and $0.410 \mathrm{kcal} / \mathrm{g}$ day, while the coefficients of variability are 17.7 and $16.8 \%$, respectively.

When oxygen consumption in the periods of maximal effort and in pericds of rest is compared it appears that at $15^{\circ} \mathrm{C}$ the maximum metabolism amounts to 5.64 and minimum to $2.72 \mathrm{cc} \mathrm{O}_{2} / \mathrm{g} \mathrm{hr}$. The ratio of maximum to minimum oxygen consumption amounts thus to 2.07. At 
$20^{\circ} \mathrm{C}$ both maximum and minimum oxygen consumption is slightly lower and amounts to 5.53 and $2.47 \mathrm{cc} \mathrm{O}_{2} / \mathrm{g} \mathrm{hr}$, respectively. The ratio of maximum to minimum oxygen consumption is hence similar to that in $15^{\circ} \mathrm{C}$ and equal to 2.24 .

The daily rhythm of activity estimated by oxygen consumption and calculated for two-hour intervals in shown in Fig. 1. The peak of metabolic activity of voles falls for night hours. The curves for both 15 and $20^{\circ} \mathrm{C}$ represent biphasic night pattern, although at $15^{\circ} \mathrm{C}$ both peaks (the first one, larger, falling for initial dark hours, and the second one smal-

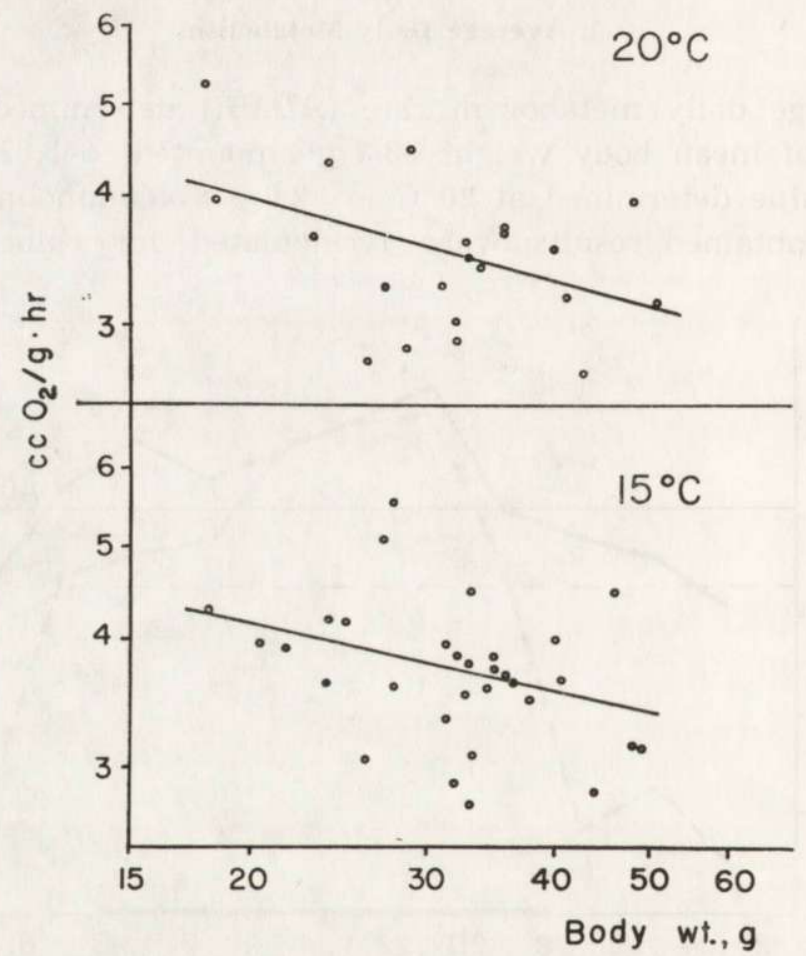

Fig. 2. Relationship between $A D M R$ and body weight.

ler, falling before dawn) are well marked. On the other hand, at $20^{\circ}$ the first peak includes a considerable part of night, and the second one smaller before dawn is less pronounced. The maximum metabolism occurring in both cases between hours 20 and 22 is very similar and amounts to $4.07\left(15^{\circ} \mathrm{C}\right)$ and $4.01 \mathrm{cc} \mathrm{O}_{2} / \mathrm{g} \mathrm{hr}\left(20^{\circ} \mathrm{C}\right)$. The metabolism at night compared with daily hours is higher at $20^{\circ}$ than at $15^{\circ} \mathrm{C}$; in the latter case the differences are small during the whole 24-hr period.

Since the weight of examined voles was comprised within rather broad limits from 18 to $50.5 \mathrm{~g}$ a relationship between average daily me- 
tabolism and body weight was estimated. The regression equation for $15^{\circ} \mathrm{C}$ is the following: $A D M R$ cc $\mathrm{O}_{2} / \mathrm{g} \mathrm{h}=8.58 \mathrm{~W}^{-0.237}$, as compared with the equation for $20^{\circ} \mathrm{C}: A D M R$ cc $\mathrm{O}_{2} / \mathrm{g} \mathrm{h}=8.75 \mathrm{~W}^{-0.264}$. These two equations are illustrated in Fig. 2.

\section{Resting Metabolism}

The course of the thermoregulation curve indicates that the thermoneutral zone for the snow vole is around $20^{\circ} \mathrm{C}$ (Fig. 3). The values obtained for the temperatures between 20 and $30^{\circ} \mathrm{C}$ are similar and equal to $6.55 \mathrm{kcal} / \mathrm{kg}^{0.75} \mathrm{~h}$. In relation to the thermoneutral zone metabolism increases by $113.9 \%$. Between the temperature of $20^{\circ} \mathrm{C}$ and $-10^{\circ} \mathrm{C}$ the

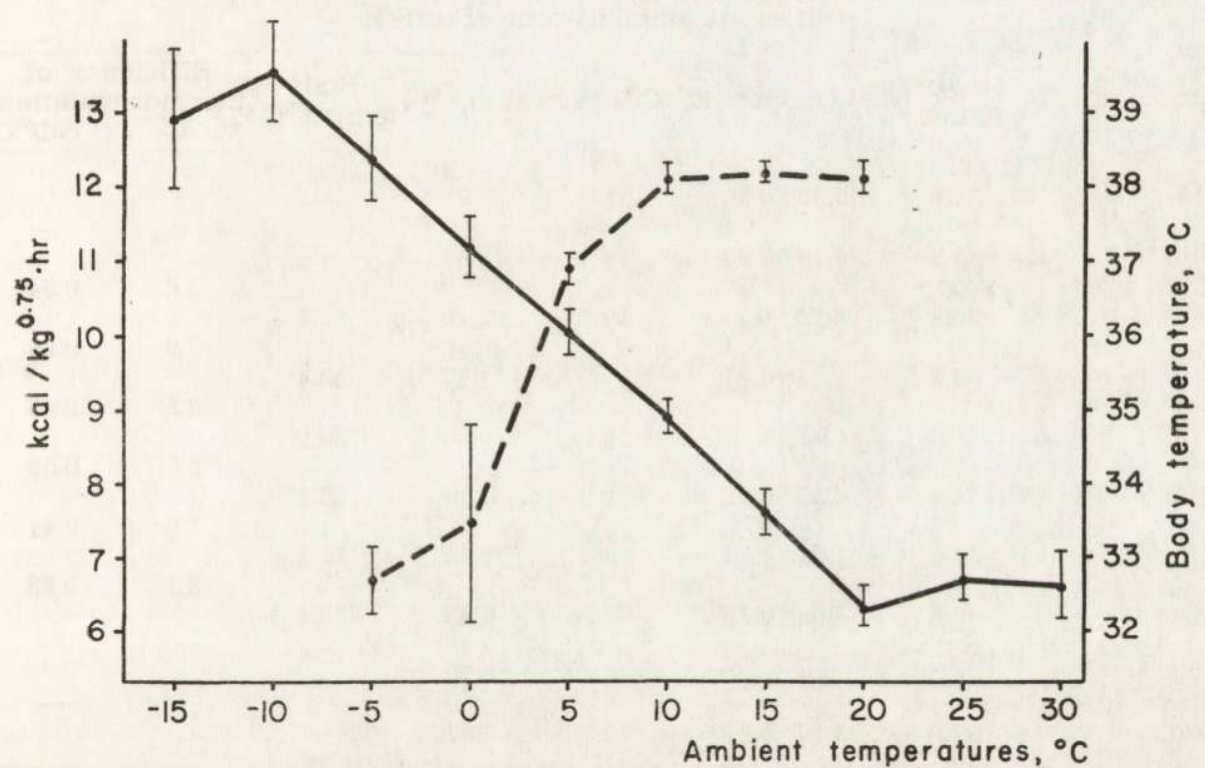

Fig. 3. Curve of thermoregulation and body temperature of Microtus nivalis; continuous line - resting metabolism $(R M R)$, broken line - body temperature; each point represents mean \pm S.D.

relationship of metabolism and ambient temperature is in principle rectilinear. These values increase from $6.33 \mathrm{kcal} / \mathrm{kg}^{0.75} \mathrm{~h}$ at $20^{\circ}$ to 13.54 $\mathrm{kcal} / \mathrm{kg}^{0.75} \mathrm{hr}$ at $-10^{\circ} \mathrm{C}$ (Table 1). With further decrease of ambient temperature (from -10 to $-15^{\circ} \mathrm{C}$ ) only a slight reduction of metabolism by $4.4 \%$ was observed. It appears that $-15^{\circ} \mathrm{C}$ is close to lethal temperature since some animals died during a longer exposure.

The efficiency of thermoregulation in the range from 20 to $-10^{\circ} \mathrm{C}$ amounts on the average to $3.8 \% /{ }^{\circ} \mathrm{C}$. In particular intervals some small 
differences are observed reaching the highest values for the interval from 20 to $15^{\circ} \mathrm{C}$, where the efficiency increases to $5.1 \% /{ }^{\circ} \mathrm{C}$ or 0.83 $\mathrm{cal} /{ }^{\circ} \mathrm{C}$ (Table 1$)$.

In the range of ambient temperature from 20 to $10^{\circ} \mathrm{C}$ the animals maintain a constant body temperature, $38.1^{\circ} \mathrm{C}$ on the average (Table 1). With further fall of ambient temperature a considerabel decrease of body temperature is observed. In the interval from $+10^{\circ} \mathrm{C}$ to $-5^{\circ} \mathrm{C}$ this decrease amounts to $14.2 \%$ (Fig. 3). This corresponds to the decrease of body temperature by $0.95 \% /{ }^{\circ} \mathrm{C}$.

Table 1

Resting metabolism, body temperature and efficiency of thermoregulation at different ambient temperatures.

\begin{tabular}{|c|c|c|c|c|c|c|c|c|}
\hline Temp., ${ }^{\circ} \mathrm{C}$ & $\mathrm{N}$ & $\begin{array}{l}\text { Body } \\
\text { wt.,g }\end{array}$ & cc $\mathrm{O}_{2} / \mathrm{g} \quad \mathrm{h} \pm \mathrm{SE}$ & C.V. $\% \mathrm{kc}$ & $\mathrm{al} / \mathrm{kg}^{0.75}$ & $\begin{array}{c}\text { Body } \\
\text { temp., }{ }^{\circ} \mathrm{C}\end{array}$ & $\begin{array}{l}\text { Effici } \\
\text { thermor } \\
\% / 0 /{ }^{\circ} \mathrm{C}\end{array}$ & $\begin{array}{l}\text { ency of } \\
\text { egulation } \\
\text { cal } /{ }^{\circ} \mathrm{C}\end{array}$ \\
\hline-15 & 5 & 35.6 & $6.39 \pm 0.59$ & 22.5 & 12.94 & - & & \\
\hline-10 & 13 & 31.8 & $6.76 \pm 0.36$ & 19.4 & 13.54 & - & & \\
\hline-5 & 13 & 32.3 & $6.20 \pm 0.34$ & 19.7 & 12.40 & 32.7 & 3.6 & 0.54 \\
\hline 0 & 12 & 33.3 & $5.52 \pm 0.27$ & 11.7 & 11.17 & 33.4 & 3.9 & 0.65 \\
\hline+5 & 33 & 35.0 & $4.95 \pm 0.18$ & 21.2 & 10.06 & 36.9 & 3.7 & 055 \\
\hline+10 & 44 & 34.8 & $4.35 \pm 0.12$ & 18.9 & 8.89 & 38.1 & 3.0 & 0.41 \\
\hline+15 & 34 & 34.3 & $3.92 \pm 0.15$ & $\approx 2.4$ & 7.93 & 38.2 & 3.1 & 0.83 \\
\hline+20 & 21 & 36.5 & $3.06 \pm 0.16$ & 24.5 & 6.33 & 38.1 & & \\
\hline+25 & 9 & 38.3 & $3.19 \pm 0.12$ & 11.0 & 6.70 & - & & - \\
\hline+30 & 7 & 37.8 & $3.16 \pm 0.21$ & 17.7 & 6.61 & - & & \\
\hline
\end{tabular}

The insulation index was calculated from the formula of $\mathrm{Hart} \&$ H éroux (1955):

$$
I_{i}=\frac{\text { Body temperature }- \text { Ambient temperature }}{\text { Oxygen consumption in } \mathrm{cc}_{2} / \mathrm{g} \mathrm{hr}}
$$

This index is the highest in the temperature of 5 and $10^{\circ} \mathrm{C}$ and amounts to 6.45 on the average. In all the remaining ambient temperatures the index is lower by $7.7 \%$ on the average.

The insulatory property of the coat determined with the Hill's katathermometer is high and equal to $2.33 \mathrm{mcal} / \mathrm{cm}^{2}$. sec on the average (at the temperature of $20 \pm 1^{\circ} \mathrm{C}$ and relative humidity of $32^{\%} \%$ ). 


\section{Daily Activity}

The daily activity of the snow vole at $15^{\circ} \mathrm{C}$ was estimated on the basis of time spent by the animal outside the nest, as divided into two-hour intervals (Fig. 4). The obtained results clearly indicate the biphasic

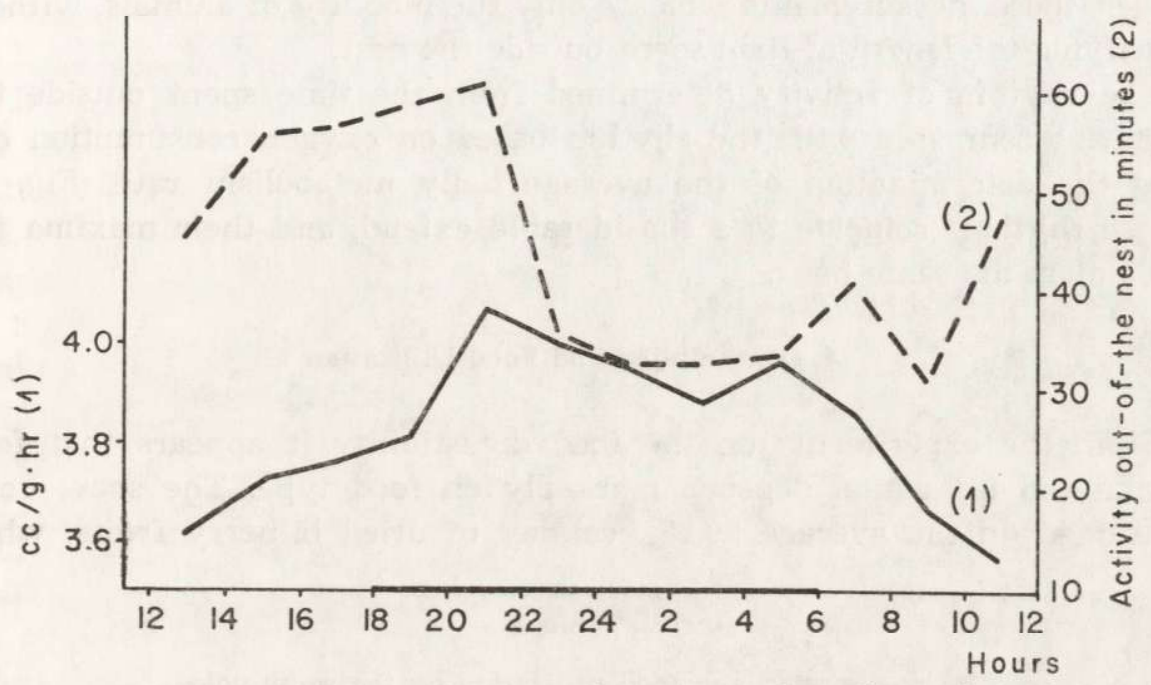

Fig. 4. Daily activity rhythm of snow voles expressed as time of staying outside the nest (broken line) and oxygen consumption at $15^{\circ} \mathrm{C}$ (continuous line).

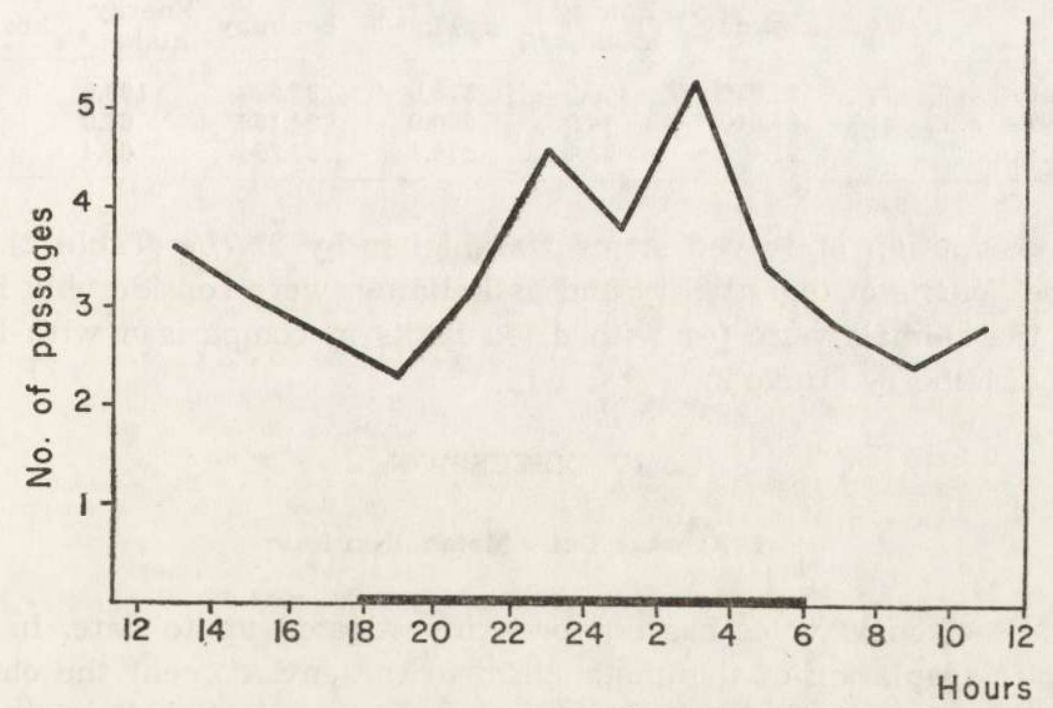

Fig. 5. Daily activity rhythm of the snow vole estimated from the number of leavings and entries to the nest. 
pattern of activity, mainly nocturnal (W o j t u siak, 1958; A s c h off, 1966) with a distinct peak between hours 20 and 22. The sum of daily activity determined as the number of entries and leavings of the nest shows the biphasic pattern (Fig. 5). The main period of activity falls for night hours $(24-6)$, and the second peak is observed around $14^{\circ}$. However, these measurements indicate only the mobility of animals, without specifying the length of time spent outside the nest.

The rhythm of activity determined from the time spent outside the nest was compared with the rhythm based on oxygen consumption during the determination of the average daily metabolism rate (Fig. 4). These rhythms coincide to a considerable extend, and their maxima fall for almost the same hour.

\section{Consumption and Food Utilization}

From the experiments on the food digestibility it appears that food intake and utilization depends markedly on food type. The snow voles consumed on the average $29.25 \mathrm{kcal} /$ day of dried bilberry fruits, while

Table 2

Consumption and food utilization by the snow vole.

\begin{tabular}{lcccccc}
\hline & \multicolumn{5}{c}{ Vaccinium myrtillus $\mathrm{L}}$. \\
\cline { 2 - 7 } & $\mathrm{c}$ Fruits & \multicolumn{3}{c}{ Leaved stems } \\
\cline { 2 - 7 } & $\mathrm{kcal} /$ day & $\begin{array}{c}\text { Energy } \\
\text { intake, \% }\end{array}$ & $\mathrm{kcal} / \mathrm{kg}^{0.75}$ & $\mathrm{kcal} /$ day & $\begin{array}{c}\text { Energy } \\
\text { intake, \% }\end{array}$ & $\mathrm{kcal} / \mathrm{k} \mathrm{g0.}^{75}$ \\
\hline Consumption & 29.250 & 100.0 & 375.0 & 35.590 & 100.0 & 468.3 \\
Digestible energy & 21.910 & 74.9 & 280.9 & 24.163 & 67.9 & 317.9 \\
Assimilation & 21.483 & 73.4 & 275.4 & 23.264 & 65.4 & 306.1 \\
\hline
\end{tabular}

the consumption of leaved stems was higher by $22.7 \%$ (Table 2). Both the coefficients of digestibility and assimilation were considerably higher when the animals were fed with dried fruits in comparison with leaved stems of bilberry (Table 2).

\section{DISCUSSION}

\section{Average Daily Metabolism Rate}

$A D M R$ of snow voles has not been investigated up to date. In order to depict adaptation of this metabolism to the environment the obtained results are compared with those of two common rodents belonging to the same family, Microtus arvalis and Clethrionomys glareolus. 
$A D M R$ of the snow vole determined at $20^{\circ} \mathrm{C}$ amounts to $3.56 \mathrm{cc} \mathrm{O}_{2} / \mathrm{g}$ $\mathrm{hr}$, and that of common vole at the same temperature is higher by $31 \%$ ( $\mathrm{rrodzinski,} \mathrm{1969).} \mathrm{However,} \mathrm{the} \mathrm{mean} \mathrm{body} \mathrm{weight} \mathrm{of} \mathrm{the} \mathrm{exa-}$ mined snow voles was considerably higher $(32.8 \mathrm{~g})$ in comparison with the common vole $(20.9 \mathrm{~g})$. Similarly $A D M R$ of the bank vole amounts to $3.95 \mathrm{cc} \mathrm{O}_{2} / \mathrm{g} \mathrm{hr}$ (G ó r e cki, 1968) (mean body weight $21.7 \mathrm{~g}$ ) and is higher from the metabolism of snow vole by $11 \%$.

In order to obtain the data independent of body weight the values of metabolism were recalculated for $\mathrm{kcal} / \mathrm{kg}^{0.75} \mathrm{hr}$ (K l e i b e r, 1961). After this recalculation the metabolism of the snow vole is lower by $15.4 \%$ from that of the common vole, and is very close to that of the bank vole.

Since the snow vole is the largest of the three compared animals the values of its metabolism were also compared with those obtained experimentally for the largest common voles $(32.0-42.0 \mathrm{~g})$ (G rodzin s ki, 1969). In such case oxygen consumption of the common vole amounted to $6.79 \mathrm{cc}_{2} / \mathrm{g} \mathrm{hr}$. Comparison of this value with $A D M R$ of the snow vole of the same weight class indicates that its metabolism is lower by $9.3 \%$. Metabolism of bank voles weighing 28-32 g (G ó r e c ki, 1968) is only slightly higher (by $5.0 \%$ ) in comparison with the metabolism of the snow vole.

Moreover, from the regression equation the metabolism of the snow vole was calculated for the range of mean body weight of compared species. The obtained value is almost identical with that of the bank vole (difference around $2 \%$ ) and slightly higher from the common vole (by $16 \%$ ).

The above considerations demonstrate considerable differences in the metabolism of snow and common voles, and small differences between snow and bank voles. Microtus arvalis is a typical lowland rodent never found in mountains above the level of lower montane zone. The bank vole, on the other hand, inhabits both lowland and mountain areas. Mountain populations of the bank vole differ significantly from the lowland ones (H a t tling e r, 1970). No physiological differences were found, however, between these two groups. It was hypothesized that in the process of evolution $C$. glareolus species was formed in mountain conditions and gradually moved to lowland areas ( $\mathrm{K}$ os telecka-My r ha, Gębczyński \& Myrcha, 1970). This hypothesis well explains a similarity in the metabolism of snow and bank voles.

In the same species also the efficiency of thermoregulation was compared in the range from $0^{\circ} \mathrm{C}$ to the thermoneutral zone. In M. arvalis and C. glareolus this zone is around $30^{\circ} \mathrm{C}$ and in $\mathrm{M}$. nivalis around $20^{\circ} \mathrm{C}$ (Fig. 3). Intensity of thermoregulation in these animals amounts to 
$6.2 \% /{ }^{\circ} \mathrm{C}$ and $5.4 \% /{ }^{\circ} \mathrm{C}$, respectively. In comparison the value of thermoregulation in the snow vole was found to be lower by 35 and $26 \%$. On the other hand, when the efficiency of thermoregulation in these three species is compared within the range from 0 to $30^{\circ} \mathrm{C}$ the value of thermoregulation of the snow vole decreases to $2.5 \% /{ }^{\circ} \mathrm{C}$ and is lower by $54 \%$ in relation to the bank vole and by $60 \%$ in relation to common vole (G órecki, 1968; G r odziński, unpubl. data). All these differences are caused probably by various body weight of compared rodents,

The results of determinations of body weight clearly indicate that snow vole is heterothermic animal in distinction to common and bank voles which show homoiothermy. Depending on the ambient temperature body temperature of the snow vole ranges from 32.7 to $38.1^{\circ} \mathrm{C}$ (Table 1). On the other hand, common and bank voles in the similar ranges of ambient temperatures maintain rather constant body temperature around $37.3^{\circ} \mathrm{C}$.

Metabolism and body temperature are related to insulatory properties which are better at all examined ambient temperatures in the snow vole than in the bank vole (by approximately 67\%) (G ó r e c ki, 1968), and than in the common vole (by approximately $82 \%$ ) (Grodziński, unpubl. data).

Also when comparing the activity of snow vole with the other two rodent species considerable differences in the sum of daily activity were observed. The activity of the bank vole (S a in t-Gir ons, 1960, 1961) is lower by $54.3 \%$, and of common vole by $26.7 \%$ in comparison with the snow vole. This is undoubtedly caused by the difference in the quality and quantity of the available food and by other environmental and climatic conditions in which these animals live.

\section{Daily Energy Budget}

$A D M R$ of the snow vole expressed as oxygen consumption at $20^{\circ} \mathrm{C}$ amounts to $3.56 \mathrm{cc} \mathrm{O}_{2} / \mathrm{g} \mathrm{hr}$ or $0.410 \mathrm{kcal} / \mathrm{g}$ day. This value presented in the form of an equation was assumed as the basis for calculation of the energy budget of the snow vole for summer and winter. The snow vole lives in mountain conditions, where the temperature in summer (June, July, August) is on the average equal to $10.4^{\circ} \mathrm{C}$, and in winter (December, January, February) as low as $-5.7^{\circ} \mathrm{C}$ (data for Morskie Oko). Since in winter the snow vole moves in rock crevices under snow cover, for calculating winter budget temperature $-0.4^{\circ} \mathrm{C}$ was employed, as the mean temperature at the depth of $5 \mathrm{~cm}$ under the ground (data of $\mathrm{Na}$ tional Institute for Hydrology and Meteorology, Zakopane). 
Intensity of heat production in the range from $20^{\circ} \mathrm{C}$ to the mean summer temperature amounts to $4.05 \% /{ }^{\circ} \mathrm{C}$ (Table 1 ). The time of staying of voles outside the nest is equal to $37 \%$ of the day. Hence the correction for thermoregulation outside the nest amounts in summer to:

$$
\left[37 \%\left(9.6^{\circ} \mathrm{C} \times 4.05 \%\right)\right]: 100=14.4 \%
$$

The summer $D E B$ is additionally increased by the costs of reproduction. It was assumed that sex ratio in the population is $1: 1$ and $30 \%$ of females are reproducing. Since the rise of energy requirements of pregnant and lactating females amounts in common and bank voles to $70 \%$ on the average ( $\mathrm{Kaczmarski}, 1966$; Trojan \& Wojciechowska, 1967; Migula, 1969), the correction calculated for all the individuals in the population is equal to $10.5 \%$. The two corrections amounting jointly to $24.9 \%$ can be added directly to the function expressing the relationship of $A D M R$ and body weight. The summer $D E B$ calculated in such way is presented in Table 3 . The whole budget may be expressed in kcal/day multiplying it by the caloric equivalent of oxygen and by 24 hours (Table 3 ).

Table 3

Daily energy budget of the snow vole for summer and
winter.

The winter $D E B$ was estimated in an analogous manner. In winter the intensity of thermoregulation amounts to $3.83 \% /{ }^{\circ} \mathrm{C}$ (Table 1). It can be assumed that activity during winter day is slightly shorter since snow voles accumulat food reserves ( $\mathrm{M}$ a r tir os j a n, 1970), and hence activity covers only $30 \%$ of the day. The correction for thermoregulation in this time amounts to $23.44 \%$. Slightly lower costs of maintenance in winter (Table 3) can be explained by good acclimatization of physical and chemical thermoregulation to low temperatures, and moreover, by the fact that winter $D E B$ is not encumbered with costs of reproduction.

When the mean budget for summer and winter: $D E B=1.25 \mathrm{~W}^{0.736}$ is calculated for the snow vole weighing $33.0 \mathrm{~g}$ it amounts to $0.497 \mathrm{kcal} / \mathrm{g}$ day, or $16.4 \mathrm{kcal} /$ animal day.

Acknowledgements: We thank cordially to Dr. A. Gó r e cki for help and valuable suggestions during the whole period of this study and to students of the Naturalist Circle, Jagiellonian University, for help during trappings.

5-Acta Theriologica t. 19 


\section{REFERENCES}

1. Aschoff J., 1966: Circadian activity pattern with two peaks. Ecology, 47, 4: $657-662$.

2. Drożd $\dot{z}$ A., 1968: Studies on the digestibility and assimilation of foods in rodents. Ekol. pol. B, 14, 2: 147-159 [in Polish with English summ.].

3. Gębczyński M. \& Olszewski J., 1963: Katathermometric measurements of insulating properties of the fur in small mammals. Acta theriol., 7, 19: $399-402$.

4. Gór e cki A., 1965: Calorimeter in ecological research. Ekol. pol. B, 11: 145-158 [in Polish with English summ.].

5. Górecki A., 1968: Metabolic rate and energy budget of bank vole. Acta theriol., 13, 20: 341-365.

6. Górecki A. \& Hanusz T., 1968: A simple indicator for registering the activity of small mammals. Ekol. pol. B, 14, 1: 33-37 [in Polish with English summ.].

7. Grodziński W., 1969: Two measures of metabolic rate in common voles, Microtus arvalis (P a 11.). [In: "Energy metabolism of farm animals", K. L. Blaxter, G. Thorbek \& J. Kielanowski, Edts.] E.A.A.P. Publ. No. 12: 399-400. Oriel Press Ltd. Newcastle.

8. Haitlinger R., 1970: Morphological characters of mountain populations of Clethrionomys glareolus (S c hre ber, 1780) and Apodemus agrarius (P a 11 a s, 1773). Acta theriol., 15, 18: 269-282.

9. Hart J. \& Héroux O., 1955: Exercise and temperature regulations in lemmings and habbits. Canad. J. Biochem. Physiol., 33: 428-435.

10. Kaczmarski F., 1966: Bioenergetics of pregnancy and lactation in the bank vole. Acta theriol., 11, 19: 409-417.

11. Kleiber M., 1961: The fire of life - an introduction to animal energetics. Wiley \& Sons. 1-454. New York, London.

12. Kostelecka-Myrcha A., Gębczyński M. \& Myrcha A., 1970: Some morphological and physiological parameters of mountain and lowland population of the bank vole. Acta theriol., 15, 8: 133-142.

13. Kowalski K., 1957: Microtus nivalis in the Carpathians. Acta theriol., 1: $159-182$.

14. Martirosjan B. A., 1970: Snežnaja polevka kak žiznennaja forma. Materialy $\mathrm{k}$ poznaniju fauny i flory SSSR. MOIP, 45, 60: 240-246.

15. Migula P., 1969: Bioenergetics of pregnancy and lactation in the European common vole (Microtus arvalis, Palla s, 1779). Acta theriol., 14, 13: 167-179 .

16. Morrison P. R. \& Grodziński W., 1968: Morrison respirometer and determination of $A D M R$. [In: Methods of Ecol. Bionergetic, Ed. W. Grodziński \& R. Klekowski]: 153-163. Pol. Acad. Sci., Warszawa-Kraków.

17. Saint Girons M. Ch., 1960: Le rythme nyctheméral d'activité du campagnol roux, Clethrionomys glareolus ( $\mathrm{S} \mathrm{chreber} 1780$ ). II - Les femalles. Mammalia. 25, 3: $342-357$.

19. Trojan P. \& Wojciechowska B., 1967: Resting metabolic rate during pregnancy and lactation in the European common vole - Microtus arvalis ( $\mathrm{P}$ a 11.). Ekol. pol. A, 15, 44: 811-817. 
20. Wojtusiak R. J., 1958: Aktywność dobowa zwierząt. Próba syntezy w pracy Jürgena Aschoffa: Aktivitätsmuster der Tagesperiodik. Kosmos A, 8, 2: 207-213 .

Accepted, June 20, 1973.

Department of Animal Ecology,

Jagiellonian University,

Krupnicza 50 ,

30-060 Kraków, Poland.

Piotr BIEŃKOWSKI i Urszula MARSZA£EK

\section{METABOLIZM I BUDŻET ENERGETYCZNY POLNIKA SNIEŻNEGO}

Streszczenie

Polniki śnieżne, Microtus nivalis ( $\mathrm{M}$ a r tins, 1842) odłowiono w Tatrach na wysokości 1400-1480 m n.p.m. w rejonie Morskiego Oka. U 46 zwierząt zbadano średni metabolizm dobowy $(A D M R)$ w 15 i $20^{\circ} \mathrm{C}$, metabolizm spoczynkowy w zakresie od -15 do $30^{\circ} \mathrm{C}$, rytm i sumy aktywności dobowej oraz konsumpcję i wykorzystanie paszy. Stwierdzono że $A D M R M$. nivalis o średnim ciężarze ciała $33 \mathrm{~g}$, w $15^{\circ} \mathrm{C}$ wynosi $3,82 \mathrm{~cm}^{3} \mathrm{O}_{2} / \mathrm{g}$ godz., a w temperaturze $20^{\circ} \mathrm{C}$ odpowiednio 3,56 (Ryc. 1, 2). Zależność $A D M R$ od ciężaru ciała przedstawiają równania: dla $15^{\circ} \mathrm{C}$ $A D M R\left(\mathrm{~cm}^{3} \mathrm{O}_{2} / \mathrm{g}\right.$ godz. $)=8,58 W^{-0,237}$, a dla $20^{\circ} \mathrm{C}$ odpowiednio $=8,75 W^{-0,264}$. Metabolizm spoczynkowy w temperaturze $-15^{\circ} \mathrm{C}$ wynosi $12,94 \mathrm{kcal} / \mathrm{kg}^{0}, 75$ godz. a w temperaturze $30^{\circ} \mathrm{C}$ równa się $6,61 \mathrm{kcal} / \mathrm{kg}^{0,75}$ godz. Strefa termoneutralna polników znajduje się w okolicy temperatury $20^{\circ} \mathrm{C}$, a krzywa termoregulacji od $-10^{\circ} \mathrm{C}$ do tej strefy jest $\mathrm{w}$ zasadzie prostoliniowa. Wydajność termoregulacji $w$ tym zakresie wynosi $3,8 \% /{ }^{\circ} \mathrm{C}$ (Tabela 1 , Ryc. 3 ).

Temperatura ciała polników mierzona przy temperaturach otoczenia od 20 do $10^{\circ} \mathrm{C}$ jest stała i wynosi średnio $38,1^{\circ} \mathrm{C}$. Natomiast przy $-5^{\circ} \mathrm{C}$ zaznacza się znaczny spadek temperatury ciała do $32,7^{\circ} \mathrm{C}$ (Tabela 1 , Ryc. 3). Polniki są aktywne przez $37 \%$ czasu doby. Rytm aktywności charakteryzuje się wzorcem dwudzielnym głównie nocnym (Ryc. 4, 5).

Polniki śnieżne pobierały średnio $29,25 \mathrm{kcal} /$ dobę suszonych owoców Vaccinium myrtillus, a konsumpcja ulistnionych pędów była wyższa o 22,7\% (Tabela 2).

Dobowy budżet energetyczny $(D E B)$ polników śnieżnych ilustruje równanie w lecie DEB (kcal/g doba)=1,26 $W^{-0,264}$, i w zimie $D E B$ (kcal/g doba) $=1,24 W^{-0,264}$. A zatem polnik ważący $33 \mathrm{~g}$ zużywa i latem i zimą $16,4 \mathrm{kcal}$ na dobę. 